\title{
Varia \\ "So I had to give it up": The role of social support for career persistence or attrition in a qualitative sample of second career teachers
}

\author{
Catherine Eve Bauer, Bern University of Teacher Education, Bern/CH \\ Larissa Maria Troesch, Bern University of Teacher Education, Bern/CH \\ Dilan Aksoy, FHNW School of Education, Windisch/CH
}

This qualitative study uses the Job Demands-Resources framework to examine social support and its role in career retention or attrition among Swiss second career teachers (SCTs). In many countries, including Switzerland, great efforts are made to bring professionals from other occupational fields into teaching. As a result, the number of SCTs is growing, as are speculations about their skills, resources, and career persistence. A qualitative content analysis of 23 semi-structured interviews shows that support from colleagues and principals is a crucial job resource for SCTs, but seems to be positively associated with work engagement and career retention only if it is offered in forms that are sensitive to SCTS' own needs and skills. Implications for SCT training and job induction are discussed.

\section{Introduction}

While the influx of professionals with prior occupational experience into teaching is a global phenomenon (Cuddapah \& Stanford, 2015) and considerable resources are being invested in their transition into teaching, empirical evidence on which to base measures for second career teachers' (SCTs') professional training and job induction is still rare. One of the key factors influencing occupational well-being is social support in the workplace (Beltman et al., 2011). This resource might be particularly important for SCTs' job satisfaction and career persistence, as SCTs' earlier career experiences tend to shape their expectations of workplace characteristics, including teamwork and social support, and can clash considerably with the realities of the school as a workplace (Bauer et al., 2017; Tigchelaar et al., 2010). Against this background, combining the theoretical framework of the Job Demands-Resources (JD-R) model with a qualitative approach, the present study examines the role of social support for career persistence or attrition among a sample of Swiss SCTs.

\section{Theoretical Framework}

2.1 Why study second career teachers?

As SCTs have become a substantial and growing teacher group in many countries (Cuddapah \& Stanford, 2015), it has become important for educational policy and practice to know more about the factors that shape their professional development as teachers as well as their long-term retention in the teaching profession. Many governments across the globe have made efforts to facilitate a fast transition into teaching, via alternative entry routes into teacher education or specialised career switcher programmes (e.g., Bauer et al., 2019; Tigchelaar et al., 2010; Trent, 2018). The urgency of these measures partly reflects the need to quickly compensate for teacher shortages, but also the benefits that individuals with prior work experience are thought to bring to the classroom, such as "real-world knowledge" and organisational skills (Trent, 2018).

Besides their relatively higher age and the fact that SCTs have made at least one career change - often accepting emotional and financial strain in the process (Johnson \& Birkeland, 2003) - empirical studies found a range of resources that might distinguish SCTs from first career teachers (FCTs): more life experience (Lovett, 2007; Wagner \& Imanel-Noy, 2014), higher self-efficacy beliefs (Troesch \& Bauer, 2017a; Weinmann-Lutz et al., 2006), higher intrinsic motivation to teach (e.g., Williams \& Forgasz, 2009; Zuzovsky \& DonitsaSchmidt, 2014), better communication skills (Freidus \& Krasnow, 1991) and greater interest in professional development (Weinmann-Lutz et al., 2006). However, SCTs might also be vulnerable to frustrations when confronted with the return to a novice status and the unfamiliar work culture at school, as well as with the gaps between their ideals and the reality of teaching as a career (Tigchelaar et al., 2010). Also, prior experience is not per se transferable to the school as a workplace, but only if SCTs are able to reflect and adapt existing skills and routines (e.g., Freidus \& Krasnow, 1991; Mayotte, 2003). 


\subsection{Attrition among first and second career teachers}

Teacher attrition refers to an avoidable loss of teachers whose long-term retention is of interest to society for institutional, economical, human resources-related or educational reasons (Kelchtermans, 2017). While attrition rates vary greatly depending on the respective school system and labour market characteristics, most countries have experienced increasing teacher attrition over the past 30 years (e.g., Ingersoll et al., 2019; Lindqvist et al., 2014).

Empirical data on SCT attrition are difficult to compare and as a result, are inconsistent. As retention intentions tend to rise with age (Borman \& Dowling, 2008) and intrinsic motivation - two characteristics that are known to be higher among SCTs (Zuzovsky \& Donitsa-Schmidt, 2014) - we would expect SCTs to have higher career commitment than FCTs. In Swiss samples, SCTs have indeed been found to be more intent to stay in teaching (Joller-Graf, 2000; Troesch \& Bauer, 2017b). Yet, depending on their training and work conditions, SCTs - particularly alternate-route teachers - may be particularly susceptible to leaving the teaching profession again quickly, not least because they have a fall-back career (e.g., Johnson \& Birkeland, 2003; Redding \& Smith, 2016). In general, SCTs seem to be more willing than their first-career colleagues to switch schools or careers until they find work environments that allow them to thrive (Johnson \& Birkeland, 2003), a tendency that might be linked to SCTs' higher self-efficacy beliefs (Troesch \& Bauer, 2017a).

\subsection{The role of social support for teacher retention and attrition}

Social support is defined as the qualitative-functional aspects of social relationships, such as perceived availability of help, or support actually received (Schwarzer \& Leppin, 1991). Borman and Dowling (2008) conclude that work conditions, including organisational features of schools like administrative support, mentoring programmes or teacher networks, are more salient for predicting teacher attrition than previously noted in the literature. Kelchtermans observes that professional relationships - with parents, students, colleagues - "operate as double-edged swords" (Kelchtermans, 2017, p. 968) as they are important sources of job satisfaction as well as of work stress.

One lens through which to look at professional resources is the JD-R model. It underlines the importance of social support as a job resource, and links it to work outcomes like the intention to stay in a job or career (Bakker \& Demerouti, 2007). The model suggests a health impairment process ensuing from high job demands, leading to stress and exhaustion, and a motivational process, fuelled by job resources and fostering employee engagement and commitment. Lack of resources is thought to weaken job motivation and lead to work disengagement and turnover intentions, either directly or mediated via job satisfaction (Bakker et al., 2007). Job resources like supervisory support and social climate have an indirect positive effect on teacher retention via job satisfaction (Pomaki et al., 2010; Skaalvik \& Skaalvik, 2011) and on organisational commitment via work engagement (Hakanen et al., 2006).

Several studies suggest that for SCTs, social support is indeed not only a resource, but the "double-edged sword" evoked by Kelchtermans (2017). In Swiss samples, SCTs tend to be considerably less satisfied than FCTs with social support and teacher collaboration at their schools (Joller-Graf, 2000; Troesch \& Bauer, 2017b). Australian and US-American studies also identified frustrations concerning school leadership and support as main sources of job dissatisfaction in samples of SCTs (Ilmer et al., 2005; Laming \& Horne, 2013).

This is relevant because dissatisfaction with organisational support has been identified as a major reason for SCTs to leave the profession again (Boyd et al., 2011; Redding \& Smith, 2016). In one of our previous studies, dissatisfaction with professional cooperation and support was a major attrition reason among Swiss SCTs as well as FCTs, but while FCTs placed more emphasis on cooperation problems with parents, the main attrition reason for SCTs was cooperation problems with colleagues and superiors (Troesch \& Bauer, 2017b). One possible explanation is that SCTs, building upon their prior experiences of teamwork and collaboration, have very specific expectations about how workplaces and teams should function (Bauer et al., 2017; Johnson, Berg, \& Donaldson, 2005). On this basis, it seems important to examine SCTs' own perspectives on social support, job satisfaction and attrition, which is the aim of the present study. Based on the JD-R model, we consider social support, firstly as a resource in the motivational process that promotes teacher commitment. Secondly, with regard to its function as a "double-edged sword", we assume that a lack of support or unhelpful support can promote negative job-related outcomes such as feelings of stress and intentions to leave teaching again, as predicted by the JD-R health impairment process. 


\section{Research questions}

Based on the literature review above as well as the JD-R model, the present qualitative study examined the relationship between social support received as a job resource and career retention or attrition among SCTs in the first years of their teaching career. We formulated the following research questions:

1. Social support as a resource: What sources and forms of social support did SCTs experience in their first years as teachers?

2. Reasons for attrition: What were the reasons for quitting teaching in those SCTs who had left teaching again by the time the study was begun?

3. Lack of support: How did SCT stayers and leavers experience the lack of social support or unhelpful support?

\section{Methods}

\subsection{Sample and context}

From a larger quantitative sample of 400 Swiss teachers who had completed a regular teaching diploma 7-10 years earlier, 135 participants gave their consent to take part in an interview. As the focus of the study was on SCTs' careers, we chose 23 participants for semi-structured interviews according to the following criteria: teachers with at least one earlier career, representing a wide scope of previous careers similar to the ones found in the quantitative sample, with an age and gender distribution that reflected the distribution in the quantitative sample (Troesch \& Bauer, 2017a, 2017b), and including persons who were still teaching (stayers) as well as persons who had left teaching again (leavers). This process resulted in a sample of 14 stayers ( 6 female) and 9 leavers (7 female). Table 1 shows the sample information.

\section{Table 1}

\begin{tabular}{|c|c|c|c|c|c|}
\hline Group & Pseudonym & Age $^{1}$ & Gender & Previous career ${ }^{1}$ & Current career ${ }^{1}$ \\
\hline \multirow[t]{14}{*}{ Stayers } & A. & Early 50 s & $\mathrm{m}$ & Draftsman & Secondary school teacher \\
\hline & B. & Mid 30s & $\mathrm{m}$ & $\begin{array}{l}\text { Employee in the transportation } \\
\text { industry }\end{array}$ & Secondary school teacher \\
\hline & D. & Mid 50s & $\mathrm{f}$ & Commercial employee & Secondary school teacher \\
\hline & E. & Early 60s & $\mathrm{m}$ & Tradesman & $\begin{array}{l}\text { Secondary school teacher, special } \\
\text { education teacher }\end{array}$ \\
\hline & F. & Mid 30s & $\mathrm{m}$ & Tradesman & Secondary school teacher \\
\hline & G. & Mid 40s & $\mathrm{m}$ & Tradesman & Secondary school teacher \\
\hline & $\mathrm{J}$. & Early 30s & $\mathrm{m}$ & Commercial employee & Secondary school teacher \\
\hline & M. & Early 50 s & $\mathrm{f}$ & Commercial employee & Vocational school teacher \\
\hline & O. & Mid 30s & $\mathrm{f}$ & Commercial employee & Kindergarten teacher \\
\hline & $\mathrm{R}$. & Late 20 s & $\mathrm{f}$ & Designer & Secondary school teacher \\
\hline & S. & Mid 30s & $\mathrm{f}$ & Health care worker & Secondary school teacher \\
\hline & T. & Mid 30s & $\mathrm{m}$ & Tradesman & Primary school teacher \\
\hline & U. & Mid 30s & $\mathrm{f}$ & Commercial employee & Primary school teacher \\
\hline & $\mathrm{V}$. & Early 60s & $\mathrm{m}$ & Designer & Secondary school teacher \\
\hline \multirow[t]{7}{*}{ Leavers } & C. & Mid 30s & $\mathrm{f}$ & Draftswoman, primary school teacher & Technician \\
\hline & $\mathrm{H}$. & Early 40s & $\mathrm{f}$ & $\begin{array}{l}\text { Commercial employee, primary } \\
\text { school teacher }\end{array}$ & Commercial employee \\
\hline & I. & Late 30 s & $\mathrm{f}$ & $\begin{array}{l}\text { Commercial employee, primary } \\
\text { school teacher }\end{array}$ & Employee in higher education \\
\hline & K. & Early 30s & $\mathrm{f}$ & $\begin{array}{l}\text { Commercial employee, secondary } \\
\text { school teacher }\end{array}$ & Unemployed (family leave) \\
\hline & L. & Late $30 \mathrm{~s}$ & $\mathrm{f}$ & $\begin{array}{l}\text { Commercial employee, secondary } \\
\text { school teacher }\end{array}$ & Health care worker \\
\hline & N. & Mid 30s & $\mathrm{m}$ & Tradesman, secondary school teacher & Engineer \\
\hline & P. & Early 40s & f & $\begin{array}{l}\text { Commercial employee, primary } \\
\text { school teacher }\end{array}$ & Employee in school administration \\
\hline
\end{tabular}




\begin{tabular}{l|l|l|l|l|l}
\hline & Q. & Mid 30s & f & $\begin{array}{l}\text { Commercial employee, primary } \\
\text { school teacher }\end{array}$ & Social worker \\
\cline { 2 - 5 } & W. & Mid 30s & $\mathrm{m}$ & Tradesman, primary school teacher & $\begin{array}{l}\text { Employee in the transportation } \\
\text { industry }\end{array}$ \\
\hline
\end{tabular}

${ }^{1}$ In order to preserve the anonymity of the participants, demographic and occupational information is presented in aggregated form.

\subsection{Procedure and Analysis}

The interviews took place at Bern University of Teacher Education where the study was conducted, had an average length of one hour and were audiotaped with the consent of the participants. The participants were asked to think of their past and current jobs as teachers, and to focus on their experiences of job challenges and success, work resources including support, career satisfaction and turnover intentions. In addition, leavers were asked about their reasons for quitting teaching.

All interviews were fully transcribed. For the analysis, approaches of directed as well as conventional qualitative content analysis according to Kuckartz (2014) were combined, i.e., certain categories (forms, sources and lack of support) were determined based on the existing literature while others (helpfulness of support, attrition reasons) were derived directly from the data. All interviews were consensually coded and, where necessary, the coding frame was adapted and refined. This process was repeated until all coded statements could be integrated in the coding frame. The document variable "stayer/leaver", based on the participants' self-declaration, was used to examine and compare patterns between active teachers and participants who had left teaching again.

Table 2 shows the coding frames for social support and attrition reasons.

Table 2

\section{Coding frame}

\begin{tabular}{l|l|l}
\hline & Code & Description \\
\hline
\end{tabular}

Sources and lack of support (deductive/directed qualitative content analysis approach, based on a scheme by Herzog et al., 2007. Designed as two separate coding schemes - one for sources of support and one for lack thereof - but with identical categories)

\begin{tabular}{l|l|l}
\hline \multirow{2}{*}{} & Colleagues & Work colleagues, incl. predecessors \\
\cline { 2 - 3 } & School leaders & Current and former principals, school managers \\
\cline { 2 - 3 } & External professionals & University teachers, professional experts, coaches, therapists \\
\cline { 2 - 3 } & Students & Students/pupils the participants were teaching or had taught \\
\cline { 2 - 3 } & In-house experts & In-school mentors, special education teachers, school social workers \\
\cline { 2 - 3 } & Teachers from other schools & Colleagues from different schools \\
\cline { 2 - 3 } & Parents & Students' parents \\
\cline { 2 - 3 } & Other & Not applicable to categories above \\
\hline \multirow{2}{*}{} & Family or partner & Family, including partners, own parents, children, siblings and other relatives \\
\cline { 2 - 3 } & Friends & Important persons outside family \\
\cline { 2 - 3 } & Other & Not applicable to categories above \\
\hline
\end{tabular}

Forms of support (deductive/directed qualitative content analysis approach, based on Schwarzer \& Knoll, 2007)

\begin{tabular}{l|l|l}
\hline & Emotional & Recognition, trust, encouragement, attention, sympathy \\
\hline & Instrumental & $\begin{array}{l}\text { Assistance, e.g. collaborative lesson planning and programming, providing teaching } \\
\text { materials, giving specific (didactic) advice }\end{array}$ \\
\hline & Informational & Receiving information, discussing issues, sharing experiences \\
\hline & Other & Not applicable to categories above \\
\hline
\end{tabular}

Helpfulness of support (inductive/conventional qualitative content analysis approach, derived directly from the text data)

\begin{tabular}{l|l|l}
\hline & Helpful & Support that helped deal with challenges or facilitate solutions \\
\hline & Unhelpful & Support that did not help deal with challenges or facilitate solutions \\
\hline & Unclear/Other & Support that is unclear or ambivalent regarding helpfulness \\
\hline
\end{tabular}


Reasons for attrition (inductive/conventional qualitative content analysis approach, derived directly from the text data)

\begin{tabular}{l|l|}
\hline & Interest in new professional challenges \\
\hline & High job demands (workload, intensity, time management) \\
\hline & Lack of support and team culture \\
\hline & Combining work and family or second job \\
\hline & Working conditions (salary, contract) \\
\hline & Doubts about own professional aptitude \\
\hline & Concrete job offer \\
\hline & Specific problems at work \\
\hline & Work with parents \\
\hline
\end{tabular}

\section{Findings}

5.1 Research question 1: Social support as a job resource

All SCTs have experienced social support in a challenging situation at least once, either solicited or received spontaneously, most often from colleagues and/or school principals. Table 3 shows the frequencies and anchor examples; categories from the coding frame that were mentioned by fewer than four persons were omitted.

\section{Table 3}

Sources and forms of support

\begin{tabular}{|c|c|c|c|}
\hline Code & $\begin{array}{c}\text { Stayers } \\
n=14\end{array}$ & $\begin{array}{r}\text { Leavers } \\
n=9\end{array}$ & Anchor Examples \\
\hline \multicolumn{4}{|c|}{ Sources of support } \\
\hline Colleagues & 13 & 7 & $\begin{array}{l}\text { "He [my predecessor] trusted me, but he briefed me very well, he showed me } \\
\text { what to do with the students." }\end{array}$ \\
\hline School leaders & 13 & 5 & "I had a great principal who was, like: 'Just drop by whenever you need to'." \\
\hline $\begin{array}{l}\text { External profes- } \\
\text { sionals }\end{array}$ & 9 & 3 & $\begin{array}{l}\text { "We also have regular further education courses }[\ldots] \text { where experts come to } \\
\text { talk to us about these issues." }\end{array}$ \\
\hline Students & 3 & 4 & $\begin{array}{l}\text { "Afterwards I got a phone call [...] because my former class wanted me to do } \\
\text { the teaching substitution again." }\end{array}$ \\
\hline In-house experts & 4 & 3 & $\begin{array}{l}\text { "The social educator also worked closely with these children, and we just kept } \\
\text { in touch afterwards." }\end{array}$ \\
\hline Parents & 4 & 1 & $\begin{array}{l}\text { "I think I had a certain goodwill from parents, I wasn't ... scrutinized as much } \\
\text { as other colleagues who became teachers straight from school." }\end{array}$ \\
\hline Family or partner & 3 & 2 & "And of course, I could talk a lot with my parents or even with my brother." \\
\hline Other & 3 & 2 & "So I had support from different sources, but it just, it didn't work out." \\
\hline \multicolumn{4}{|l|}{ Forms of support } \\
\hline Emotional & 10 & 5 & "And I always felt the children really appreciated me, and that helped too." \\
\hline Instrumental & 10 & 5 & $\begin{array}{l}\text { "And then we corrected [the tests] the three of us, across classes, and things } \\
\text { like that are just really good." }\end{array}$ \\
\hline Informational & 12 & 7 & "I discussed it a lot with family and friends. Should I, shouldn't I [quit]?" \\
\hline
\end{tabular}

Note. Categories mentioned by fewer than four persons were omitted.

Concerning support from colleagues, exchange of information (sharing tips and advice, job-relevant information or discussing school matters) and exchange of teaching material (scripts, course material etc.) were the most frequently mentioned forms of support. They were often greatly appreciated because they provided reassurance and helped save time. The most frequent forms of support from school principals were backup in challenging situations with students or parents, effective leadership (good school culture and collaboration among the staff, fair distribution of responsibilities), support in developing a teaching style, as well as assistance with difficult decisions, e.g., with school transitions. F.'s quote illustrates how multifaceted the impact of principal support can be: 
We've got a principal now who... who's really very good, and that's why I eventually joined that task group [he had invited me to join]. My work has improved, and I get more work done. I like to offer my help, simply because our collaboration has become so good. I feel that I'm being taken seriously.

In this quote, support from the principal is described as part of an inclusive, encouraging work culture with several positive implications: a strong sense of competence ("I do better work"), an increase in work engagement ("I get more done"), social relatedness/contribution (joining task group, offering help), job satisfaction (good collaboration) and professional self-worth ("being taken seriously").

A closer look at the forms of support from colleagues and principal revealed that 9 of the 14 stayers mentioned that they appreciated being included in a positive staff culture, and receiving support to develop and adapt their professional skills (with programming, classroom management, parent communication, exams and grading or school development):

We had a strong staff community, we supported and sustained each other [...] it's a small school and we had a goo-, a really good time. (O.)

And also, during these exam periods I could count on the team since we have a very good headteacher. Its just an area where he has supported us a lot. (A.)

On the other hand, only two leavers talked about a positive staff culture; overall, their accounts focused on more isolated forms of support from individual teachers, parents or supervisors. It is unclear whether the leavers rarely experienced these forms of support or just did not talk about them, but the interviews show that among the stayers, a school culture that was characterised by a general openness for discussion, exchange and collaboration helped ease the transition from newcomer to established member of the teaching staff. In the most positive accounts of stayers, their skills and limits were equally acknowledged, they were encouraged to learn and develop their skills, and were open to accepting support.

\subsection{Research question 2: Reasons for quitting teaching}

Table 4 shows the frequencies of attrition reasons among the leavers. Most SCTs had not one, but several reasons for quitting teaching, but three overarching themes emerged from the analysis: new challenges, high demands and lack of support.

\section{Table 4}

\section{Frequencies of attrition reason}

\begin{tabular}{|c|c|c|c|c|c|c|c|c|c|c|}
\hline Codes / Participants & C. & I. & K. & Q. & N. & P. & H. & L. & W. & Frequency \\
\hline Interest in new professional challenges & - & $\mathrm{x}$ & - & $\mathrm{x}$ & $\mathrm{x}$ & $\mathrm{x}$ & $\mathrm{x}$ & $\mathrm{x}$ & $\mathrm{x}$ & 7 \\
\hline $\begin{array}{l}\text { High job demands (workload, intensity, time } \\
\text { management) }\end{array}$ & $\mathrm{x}$ & $\mathrm{x}$ & - & $\mathrm{x}$ & - & - & $\mathrm{x}$ & $\mathrm{x}$ & $\mathrm{x}$ & 6 \\
\hline Lack of support and team culture & - & - & - & $\mathrm{x}$ & $\mathrm{x}$ & $\mathrm{x}$ & $\mathrm{x}$ & $\mathrm{x}$ & $\mathrm{x}$ & 6 \\
\hline Combining work and family or second job & - & $\mathrm{x}$ & $\mathrm{x}$ & - & - & $\mathrm{x}$ & - & $\mathrm{x}$ & - & 4 \\
\hline Working conditions (salary, contract) & - & $\mathrm{x}$ & - & - & - & - & $\mathrm{x}$ & - & $\mathrm{x}$ & 3 \\
\hline Doubts about own professional aptitude & - & - & - & $\mathrm{x}$ & - & - & - & $\mathrm{x}$ & - & 2 \\
\hline Concrete job offer & - & - & - & $\mathrm{x}$ & - & - & - & $\mathrm{x}$ & - & 2 \\
\hline Specific problems at work & - & $\mathrm{x}$ & - & - & - & - & - & - & $\mathrm{x}$ & 2 \\
\hline Work with parents & - & - & - & - & - & - & - & $\mathrm{x}$ & - & 1 \\
\hline
\end{tabular}

Notes. $\mathrm{x}=$ mentioned, $-=$ not mentioned.

Except for K., whose only reason for quitting was difficulties reconciling family and career, the main reasons were found within one of these three themes or a combination of them:

- New challenges: a strong interest in seeking new challenges in the form of professional development, or a new career within or outside of education. Two participants even had a specific job offer

- High job demands: high intensity, feelings of overwork and work pressure, often due to difficulties setting limits (limiting work hours, preserving energy), and often combined with feelings of exhaustion

- Lack of support and team culture: feeling alone, missing team culture and exchange, feeling isolated or rejected, or feeling patronised by well-intended support 
Several teachers were able to give an accurate account of how these three factors interacted and contributed to the decision to quit teaching. Most teachers liked teaching, emphasizing it was not the high job demands as such that made them quit, but the combination of this reason with feelings of isolation and lack of support and/or a strong interest in finding an equally stimulating but less draining work environment. H. sums up her decision like this:

So, I had to give up, I had nightmares and I just collapsed [...] Of course I also put a lot of pressure on myself, I never took a vacation in that first year, I always slept poorly, always thinking 'oh you should still do this and then that, and that, and that'. I never, never had any form of exchange [within the school].

In this quotation, the reason of high job demands (work pressure, workload) is apparent, as is lack of support and, as a consequence, severe exhaustion. For H., the lack of support was the most important reason for attrition:

I did not quit because of the children and I did not quit because of the parents. Or the salary. [...] I just, I just really missed having a team.

\subsection{Research question 3: Lack of support and unhelpful support}

Among both stayers and leavers, lack of support from colleagues, principals and other professionals at their school was reported most frequently; lack of support from the private environment was mentioned very rarely (see table 5).

\section{Table 5}

Lack of support and unhelpful support

\begin{tabular}{lrrr}
\hline Code & Stayers & Leavers & Anchor Examples \\
& $n=14$ & $n=9$ & \\
\hline
\end{tabular}

Lack of support

\begin{tabular}{|c|c|c|c|}
\hline Colleagues & 8 & 5 & $\begin{array}{l}\text { "From the staff [...] I would have wished for more support, also for trivial } \\
\text { things like ski day." }\end{array}$ \\
\hline School principals & 9 & 4 & $\begin{array}{l}\text { "Unfortunately, I could not rely on the principal very much. The information } \\
\text { flow was very scant, inexistent, or at very short notice." }\end{array}$ \\
\hline In-house experts & 5 & 2 & "In my first year, I have had no, no mentor." \\
\hline Other & 6 & 5 & $\begin{array}{l}\text { "I would have to start at experience level zero; the fact that I had more } \\
\text { training and more years of experience than a first career teacher was never up } \\
\text { for discussion." }\end{array}$ \\
\hline
\end{tabular}

Helpfulness of support

\begin{tabular}{lrll}
\hline Helpful & 14 & 7 & "I really had quite a gentle job induction." \\
Unhelpful & 4 & 6 & "So I had support from different sources, but it just, it didn't work out." \\
Unclear/Other & 4 & 2 & "She [the principal] supported me quite well, but almost too firmly." \\
\hline
\end{tabular}

A closer look into the areas and themes of lack of support revealed that for many stayers and leavers, not having had a mentor or good job induction were the most prominent areas. However, while stayers seem to have been able to leave these frustrations behind them with time, four leavers mentioned a lack of leadership that continued to bother them and that felt very wrong compared to their former career:

In my opinion, a superior can't, well he'd have to, I don't know, evaluate my work on a weekly or monthly basis in order to know what I'm doing [...] but he was never interested in things like that. Ever. (N.)

[I expected him] to establish a clear structure, to simply be a leader. (H.)

Concerning helpfulness of support, the frequencies show that while all stayers had experienced episodes of helpful support, two leavers did not mention any helpful support at all, and those who did were more ambivalent about the support received: six leavers emphasized that they got support from colleagues and/or school principals which they perceived as not helpful or ambivalent because it conflicted with their own professional goals and ideals or with their sense of autonomy. For example, W. and C. felt so out of place and inept in their new role as teachers that even when they got support, they felt it did not help: 
She [the principal] always said everyone could just drop by and ask, but [... you don't always want to be the one who is like 'oh please, now can you help me'. (W.)

Sure, there were always people [at work] telling me 'Just try it for a year, half a year, you're being thrown in at the deep end, but you'll be fine', but I somehow realised that this is not what I want. (C.)

A form of social support that frequently triggered a defensive reaction among the leavers was specific, unidirectional informational support that can be described as "good advice". Not all participants were ready to comply with advice about how to deal with their job demands, or statements about how things had always been done at their school, and it seems that the leavers were particularly prone to feel irritated by this kind of support. When trying out new ways of cooperating with parents of a disruptive student, L. received support that he found unacceptable because it was incongruent with his work ethic:

There were a lot of old hands in my school team. They were like, 'that's how things are, accept it". But I didn't want to. That's not who I am. I always try to get everyone on board. And I think that the kids deserve this, they deserve us to undertake the journey together, with their parents, well, parents and teachers together with the kid

[...] But my colleagues said: 'You should just handle it the way we told you'.

The interaction as L. remembers it, although not helpful in his opinion, can be defined as informational as well as emotional support, since it includes both guidance to solve the problem ("handle it the way we told you") as well as reassurance that there is no need to worry or work himself up ("that's how things are"). However, it is not the kind of inclusive and encouraging support that feels empowering, as it does not allow for much creative leeway. Similarly, N. talked about how he frequently turned down offers of support because as an experienced professional, he did not want to be treated as a novice:

Well, perhaps it was a disadvantage that I already knew so much, and, of course, sometimes I actually knew things better [chuckles]. Sometimes I'd say, maybe a bit smug: 'No! I don't need this [your help], I won't do this, mind your own business'. Or I'd say: 'That's all well and good, but I'll do it my way'.

N.'s quote shows how support can be perceived not only as a job resource, but as an additional demand that has to be dealt with.

\section{Discussion}

In the context of increasing career mobility and periods of teacher shortages, second career teachers (SCTs) are a growing part of the teacher workforce in many countries, and there is increasing interest in their job induction and retention. Drawing on the Job Demands-Resources (JD-R) model, this qualitative study examined the link between social support received and career retention or attrition in a sample of Swiss SCTs that included both current teachers as well as SCTs who had quit teaching again.

Across the sample, support within the school - i.e., support that can be referred to as organisational support - was very common. However, there was a distinct difference between stayers and leavers; the stayers repeatedly talked about being welcomed into an inclusive team culture that allowed them to grow and contribute. The leavers on the other hand rarely talked about support that went beyond occasional help from individual colleagues and supervisors, and they generally felt less included and encouraged. They doubted or resisted offers of support considerably more often than stayers. For all but one of the leavers, feelings of isolation, overwork and/or opportunity were the main reasons for quitting teaching, making organisational support one of the prominent factors in deciding to quit.

These qualitative findings are in line with quantitative JD-R research: feelings of isolation can be understood as an indicator for lack of job resources, while overwork can be interpreted as the result of high job demands in combination with poor job resources (Schaufeli \& Taris, 2014); both are known to be associated with turnover intentions and attrition (e.g., Bakker et al., 2007). Nevertheless, it is important to keep in mind that work characteristics are not the only important factors for SCT attrition, but also factors outside the current work setting such as job opportunities or interest in professional advancement. Another aspect to consider is that in the Swiss employment context, teachers are responsible for their own job placements, i.e., they are free to leave one school and teach at another if they are dissatisfied with the resources at their school. This could mean that the SCTs who had left the profession again were more dissatisfied with aspects of the profession rather than with aspects of their job environment. 
Overall, the leavers had more problems adjusting to their new work environment, feeling included, and accepting support than the stayers. This leads us to two questions: does organisational support play a specific role for SCT job induction, and do SCTs have specific needs regarding organisational support?

\subsection{What role does organisational support play for SCT job induction?}

The increasing number of SCT programmes worldwide not only reflects the need to swiftly fill personnel gaps, but also the common expectation that by employing SCTs, schools can benefit from their cumulative wealth of professional knowledge and skills (Trent, 2018). Yet, there is evidence that this transfer depends on SCTs' ability to reflect and adapt their existing skills and routines (e.g., Mayotte, 2003), as preconceived beliefs and routines can even interfere with professional development (Tigchelaar et al., 2010). Our analyses uphold the assumption that support from colleagues and principals might be an essential facilitating factor in career transition. Leaving teaching again was often associated with the inability to overcome the "culture shock" that many SCTs felt when transitioning into their new career. However, the stayers seem to have had more resources to cope with this challenge. Our analyses suggest that among SCTs, encouraging organisational support, the ability to reflect and adapt existing work routines and expectations, and the development of a long-term work commitment are closely related. Future research could explore these relationships in more detail.

\subsection{Do SCTs have specific needs regarding organisational support?}

Our findings show that while organisational support was a crucial job resource for SCTs, it did not automatically have a positive impact on SCTs' work engagement and retention: although the leavers did receive social support in the workplace, they were distinctly less satisfied with it, and less open to accept support offered than the stayers. According to our data, support from school leaders and colleagues seems to be particularly effective for SCTs' engagement and commitment if it is grounded in a supportive school culture that connects the individual teachers, strengthens their autonomy, helps them develop their skills and lets them contribute to school development activities - forms of support that correspond very well with what Self-Determination Theory calls "engaging leadership" (Schaufeli, 2015). Engaging leaders promote the fulfilment of employee's basic psychological needs for autonomy, competence and relatedness by inspiring, strengthening and connecting them, respectively - resources that have been shown to be associated with high work engagement (Deci \& Ryan, 2012).

However, several of the leavers perceived the support provided as limiting or patronizing; this is not unexpected given the experience that SCTs have as professionals in other fields, and the power imbalance implied in social support (Zimet et al., 1988). Also, isolated experiences of support did not spark the same positive process regarding work engagement and retention as an encouraging school culture: The exchange of views and teaching material with individual colleagues was highly appreciated but not associated with high work engagement. What is more, support in the form of "good advice" provoked resistance and disengagement, possibly because it interfered with autonomy and competence - a process that has been associated with negative effects on work engagement and commitment (Lewis \& Rook, 1999). Research focusing on basic need satisfaction among SCTs might be fruitful to shed further light on these relationships.

\subsection{Limitations and future research}

The cross-sectional, retrospective design of the study entails certain limitations. We cannot rule out the possibility that leavers, e.g., for reasons of self-legitimation, overemphasized the lack of organisational support in retrospect, or were offered more social support than they now remember. A longitudinal, multi-perspective approach would help to minimize this possibility. Furthermore, we did not include job demands as a category in the coding scheme. According to the JD-R model, resources have a positive effect on motivation and commitment particularly when demands are high (Bakker \& Demerouti, 2007). Our finding that lack of organisational support was a major reason for attrition, often in combination with exhaustion due to high workload, implying that lack of social support had negative organisational consequences particularly when job demands were high. In order to examine these processes more thoroughly, the interaction of social support with job demands should be examined more closely in future studies. Finally, it has yet to be established to what extent our findings can be generalized to other samples of SCT, as the sample consisted mainly of people who had obtained a degree in vocational education in their first professional career and then went on to complete a regular teacher training programme. 


\section{4 Conclusions}

The present study, examining the link between social support as a job resource and teacher attrition, corroborates aspects of the JD-R model from a qualitative perspective, and particularly for second career teachers (SCTs). Organisational support seems to be a particularly crucial resource for beginning SCTs as it might help them adapt existing routines and expectations. The findings suggest that social support that offers occasional help or advice without nurturing a sense of relatedness or being sensitive to SCTs' competence does not seem to have the same positive effect on work engagement and career persistence as an encouraging school culture. School leaders should keep in mind that beginning SCTs - despite their expertise in other domains - need encouraging organisational support and a collaborative work culture in order to reflect and adapt their existing work routines and expectations, and establish a successful new career.

\section{References}

Bauer, C. E., Aksoy, D., Trösch, L. M., \& Hostettler, U. (2017). Herausforderungen im Lehrberuf: Die Bedeutung vorberuflicher Erfahrungen. In C. E. Bauer, C. Bieri Buschor, \& N. Safi (Eds.), Berufswechsel in den Lehrberuf. Neue Wege der Professionalisierung (pp. 119-138). hep Verlag.

Bauer, C. E., Bieri Buschor, C., \& Bürgler, B. (2019). Quereinstieg: Berufswechsel in den Lehrberuf in der Schweiz. Journal für LehrerInnenbildung, 19(2), 14-27. https://doi.org/10.35468/jlb-02-2019_01

Bakker, A. B., \& Demerouti, E. (2007). The Job Demands-Resources model: state of the art. Journal of Managerial Psychology, 22(3), 309-328. https://doi.org/10.1108/02683940710733115

Bakker, A. B., Hakanen, J. J., Demerouti, E., \& Xanthopoulou, D. (2007). Job resources boost work engagement, particularly when job demands are high. Journal of Educational Psychology, 99(2), 274-284. https://doi.org/10.1037/0022-0663.99.2.274

Beltman, S., Mansfield, C., \& Price, A. (2011). Thriving not just surviving: A review of research on teacher resilience. Educational Research Review, 6(3), 185-207. https://doi.org/10.1016/j.edurev.2011.09.001

Borman, G. D., \& Dowling, N. (2008). Teacher attrition and retention: A meta-analytic and narrative review of the research. Review of Educational Research, 78(3), 367-409. https://doi.org/10.3102/0034654308321455

Boyd, D., Grossman, P., Ing, M., Lankford, H., Loeb, S., \& Wyckoff, J. (2011). The influence of school administrators on teacher retention decisions. American Educational Research Journal, 48(2), 303-333. https://doi.org/10.3102/0002831210380788

Cuddapah, J. L., \& Stanford, B. H. (2015). Career-changers' ideal teacher images and grounded classroom perspectives. Teaching and Teacher Education, 51, 27-37. https://doi.org/10.1016/j.tate.2015.05.004

Deci, E. L., \& Ryan, R. M. (2012). Motivation, personality, and development within embedded social contexts: An overview of self-determination theory. In R. M. Ryan (Ed.), The Oxford handbook of human motivation (pp. 85-107). Oxford University Press. http://dx.doi.org/10.1093/oxfordhb/9780195399820.013.0006

Freidus, H., \& Krasnow, M. (1991). Second Career Teachers: Themes and variations. Paper presented at the Annual Meeting of the American Educational Research Association, Chicago, April 1991.

Hakanen, J. J., Bakker, A. B., \& Schaufeli, W. B. (2006). Burnout and work engagement among teachers. Journal of School Psychology, 43(6), 495-513. https://doi.org/10.1016/j.jsp.2005.11.001

Herzog, W., Herzog, S., Brunner, A., \& Müller, H. P. (2007). Einmal Lehrer, immer Lehrer. Haupt Verlag.

Ilmer, S., Elliott, S., Snyder, J.-A., Nahan, N., \& Colombo, M. (2005). Analysis of urban teachers 1 st year experiences in an alternative certification program. Action in Teacher Education, 27(1), 3-14. https://doi.org/10.1080/01626620.2005.10463369

Ingersoll, R., Merrill, E., Stuckey, D., \& Collins, G. (2019). The Changing Face of the Teaching Force in the United States. In C.E. Bauer, N. Safi \& M. Kocher (Eds.), Lehrberuf: Vorbereitung, Berufseinstieg, Perspektiven. Beiträge aus der Professionsforschung (pp. 197-215). hep Verlag.

Johnson, S. M., \& Birkeland, S. E. (2003). Pursuing a "sense of success": New teachers explain their career decisions. American Educational Research Journal, 40(3), 581-617. https://doi.org/10.3102/00028312040003581

Johnson, S. M., \& Kardos, S. M. (2005). Bridging the generation gap. Educational Leadership, 62(8), 8-14.

Joller-Graf, K. (2000). Selbstwahrnehmung von Lehrerinnen und Lehrern des zweiten Bildungswegs. Beiträge zur Lehrerbildung, 18(2), 192-198.

Kelchtermans, G. (2017). 'Should I stay or should I go?': unpacking teacher attrition/retention as an educational issue. Teachers and Teaching, 23(8), 961-977. https://doi.org/10.1080/13540602.2017.1379793

Kuckartz, U. (2014). Qualitative Inhaltsanalyse. Methoden, Praxis, Computerunterstützung. Beltz.

Laming, M. M., \& Horne, M. (2013). Career change teachers: pragmatic choice or a vocation postponed? Teachers and Teaching, 19(3), 326-343. https://doi.org/10.1080/13540602.2012.754163

Lewis, M. A., \& Rook, K. S. (1999). Social control in personal relationships: Impact on health behaviors and psychological distress. Health Psychology, 18(1), 63. https://doi.org/10.1037/0278-6133.18.1.63

Lindqvist, P., Nordänger, U. K., \& Carlsson, R. (2014). Teacher attrition the first five years - A multifaceted image. Teaching and Teacher Education, 40(0), 94-103. https://doi.org/10.1016/j.tate.2014.02.005

Lovett, S. (2007). "Teachers of promise": Is teaching their first career choice? New Zealand Annual Review of Education, 16, $29-53$. https://doi.org/10.26686/nzaroe.v0i16.1510

Mayotte, G. A. (2003). Stepping stones to success: previously developed career competencies and their benefits to career switchers transitioning to teaching. Teaching and Teacher Education, 19(7), 681-695. https://doi.ort/10.1016/j.tate.2003.03.002

Pomaki, G., DeLongis, A., Frey, D., Short, K., \& Woehrle, T. (2010). When the going gets tough: Direct, buffering and indirect effects of social support on turnover intention. Teaching and Teacher Education, 26(6), 1340-1346. https://doi.org/10.1016/j. tate.2010.03.007 
Redding, C., \& Smith, T. M. (2016). Easy in, easy out: Are alternatively certified teachers turning over at increased rates? American Educational Research Journal, 53(4), 1086-1125. https://doi.org/10.3102/0002831216653206

Schaufeli, W. B. (2015). Engaging leadership in the job demands-resources model. Career Development International, 20(5), 446-463. https://doi.org/10.1108/CDI-02-2015-0025

Schwarzer, R., \& Knoll, N. (2007). Functional roles of social support within the stress and coping process: A theoretical and empirical overview. International Journal of Psychology, 42(4), 243-252. https://doi.org/10.1080/00207590701396641

Schwarzer, R., \& Leppin, A. (1991). Social support and health: A theoretical and empirical overview. Journal of Social and Personal Relationships, 8(1), 99-127. https://doi.org/10.1177/0265407591081005

Skaalvik, E. M., \& Skaalvik, S. (2011). Teacher job satisfaction and motivation to leave the teaching profession: Relations with school context, feeling of belonging, and emotional exhaustion. Teaching and Teacher Education, 27(6), 1029-1038. https:// doi.org/10.1016/j.tate.2011.04.001

Tigchelaar, A., Brouwer, N., \& Vermunt, J. D. (2010). Tailor-made: Towards a pedagogy for educating second-career teachers. Educational Research Review, 5(2), 164-183. https://oi.org/10.1016/j.edurev.2009.11.002

Trent, J. (2018). "It's like starting all over again". The struggles of second-career teachers to construct professional identities in Hong Kong schools. Teachers and Teaching, 24(8), 931-950. https://doi.org/10.1080/13540602.2018.1477752

Troesch, L., \& Bauer, C. E. (2017a). Second career teachers: Job satisfaction, job stress, and the role of self-efficacy. Teaching and Teacher Education, 67, 389-398. https://doi.org/10.1016/j.tate.2017.07.006

Troesch, L., \& Bauer, C. E. (2017b). Gehen oder bleiben? Berufsverbleib und Ausstiegsgründe von Berufswechslern und Berufswechslerinnen in den Lehrberuf. In C. E. Bauer, C. Bieri Buschor, \& N. Safi (Eds.), Berufswechsel in den Lehrberuf-Neue Wege der Professionalisierung (pp. 161-176). hep Verlag.

Wagner, T., \& Imanel-Noy, D. (2014). Are they genuinely novice teachers?: Motivations and self-efficacy of those who choose teaching as a second career. Australian Journal of Teacher Education, 39(7), n7. https://doi.org/10.14221/ajte.2014v39n7.5

Weinmann-Lutz, B., Ammann, T., Soom, S., \& Pfäffli, Y. (2006). Jetzt noch studieren... Berufswechsel und Studium bei Erwachsenen am Beispiel angehender Lehrerinnen und Lehrer. Waxmann.

Williams, J., \& Forgasz, H. (2009). The motivations of career change students in teacher education. Asia-Pacific Journal of Teacher Education, 37(1), 95-108. https://doi.org/10.1080/13598660802607673

Zimet, G., W. Dahlem, N., G. Zimet, S., \& K. Farley, G. (1988). The Multidimensional Scale of Perceived Social Support. Journal of Personality Assessment, 52(1), 30-41. https://doi.org/10.1207/s15327752jpa5201_2

Zuzovsky, R., \& Donitsa-Schmidt, S. (2014). Turning to teaching: Second career student teachers' intentions, motivations, and perceptions about the teaching profession. International Education Research, 2(3), 1-17.

Keywords: Second career teachers; early career teachers; social support; teacher attrition; job demands-resources model

\section{"Da musste ich aufgeben": Soziale Unterstützung und Berufsverbleib in einer qualitativen Stichprobe von Lehrpersonen auf dem zweiten Karriereweg}

\section{Zusammenfassung}

Auf der Basis des Job Demands-Resources-Modells untersucht diese qualitative Studie die soziale Unterstützung und den Berufsverbleib von Schweizer «Second Career Teachers» (SCT), die aus anderen Berufen in den Lehrberuf wechselten. In vielen Ländern, inklusive der Schweiz, werden SCT zunehmend für den Lehrberuf rekrutiert, um Personalmangel aufzufangen. Unklar ist, welche Ressourcen SCT mitbringen und ob sie im Beruf verbleiben. 23 Leitfadeninterviews wurden mittels qualitativer Inhaltsanalyse ausgewertet. Die soziale Unterstützung durch Schulleitende und Kolleg*innen ist eine zentrale Ressource für SCT, für Arbeitsengagement und Verbleibabsicht aber v.a. dann bedeutsam, wenn sie auf die Bedürfnisse und Kompetenzen der SCT abgestimmt ist. Der Artikel diskutiert Konsequenzen für Ausbildung und Berufseinstieg von SCT.

Schlagworte: Quereinstieg; Berufseinstieg in den Lehrberuf; soziale Unterstützung; Berufsausstieg von Lehrpersonen; Job demands-resources model 


\section{"Alors j'ai dû abandonner" : Le rôle du soutien social dans la poursuite ou l'abandon de carrière dans un échantillon qualitatif d'enseignant·ess en deuxième carrière}

Résumé

Basée sur le modèle Job Demands-Resources, cette étude qualitative examine le rôle du soutien social dans la poursuite ou l'abandon de carrière d' enseignant.e.s suisses en deuxième carrière (EDC). Dans de nombreux pays, dont la Suisse, des efforts importants sont faits en vue du recrutement de personnel enseignant issu d'autres champs professionnels. Cela entraine une augmentation du nombre d'EDC en même temps que cela questionne leurs compétences, leurs ressources et leur durée dans la profession enseignante. Une analyse de contenu qualitative de 23 entretiens semi-directifs montre que le soutien social de la part des collègues et des directeurs et directrices d'école est une ressource professionnelle essentielle pour les EDC, mais qu'elle ne semble positivement associée à leur engagement professionnel et à la poursuite de leur carrière que si elle est adaptée à leurs besoins et compétences. Les implications pour la formation et l'insertion professionnelle seront discutées.

Mots-clés : Reconversion professionnelle dans l'enseignement; enseignant.e.s en deuxième carrière ; soutien social ; abandon de carrière des enseignant.e.s; modèle job demands-resources

\section{"E così ho dovuto abbandonare": Supporto sociale e permanenza o abbandono nella professione in un campione qualitativo di Second Career Teachers}

\section{Riassunto}

Questo studio qualitativo utilizza il modello del Job Demands-Resources per analizzare il supporto sociale e il ruolo che questo gioca nella possibilità di mantenere o abbandonare la professione tra docenti svizzeri che hanno selezionato l'insegnamento come seconda carriera, i cosiddetti Second Career Teachers (SCTs). In molte nazioni, inclusa la Svizzera, un grande sforzo viene investito per reclutare professionisti da altre occupazioni da inserire nell'insegnamento. Di conseguenza, il numero degli SCTs sta crescendo così come le riflessioni sulle loro competenze, risorse e la loro persistenza nella carriera di insegnanti. L'analisi qualitativa di 23 interviste semistrutturate mostra che il sostegno sociale da parte dei presidi e dei colleghi costituisce una risorsa professionale cruciale per questi docenti. Tuttavia, tale sostegno risulta associato positivamente con l'impegno e la persistenza nella carriera degli SCTs solo quando offerto in forme sensibili ai bisogni e alle competenze di questi insegnanti. Le implicazioni per la formazione degli SCTs e il loro inserimento nella professione vengono discusse.

Parole chiave: Insegnanti che provengono da altre professioni; insegnanti nella prima fase di carriera; supporto sociale; abbandono della professione d'insegnante; modello job demands-resources

Larissa Maria Troesch (PhD), researcher and lecturer at the University of Teacher Education Bern, Switzerland. Research areas: Early childhood education, second language acquisition, teacher professional development. PHBern, Institute for Research, Development and Evaluation, Fabrikstrasse 2a, CH-3012 Bern.

E-mail: larissa.troesch@phbern.ch

Catherine Eve Bauer $(\mathrm{PhD})$, researcher and lecturer at the University of Teacher Education Bern, Switzerland. Research areas: Teacher professionalisation and career trajectories, second career teachers. PHBern, Institute for Research, Development and Evaluation, Fabrikstrasse 8, CH-3012 Bern. E-mail: catherine.bauer@phbern.ch

Dilan Aksoy is a PhD student at UZH, and a research assistant at the FHNW School of Education. Research areas: Violence resilience, teacher professional development.

PH FHNW, Institute for Research and Development, Bahnhofstr. 6, 5210 Windisch.

E-mail: dilan.aksoy@fhnw.ch 